\title{
Belgium's historic beer diversity: should we raise a pint to institutions?
}

\author{
Accepted Manuscript (January 24, 2019) \\ Journal of Institutional Economics
}

ELINE POELMANS

KU Leuven, Faculty of Economics and Business, campus Brussels, Brussels, Belgium eline.poelmans@kuleuven.be

JASON E. TAYLOR

Central Michigan University, Mount Pleasant, USA

Taylo2je@cmich.edu

\begin{abstract}
Despite its relatively small size, Belgium has historically been considered to have the most diverse array of beer varieties in the world. We explore whether Belgium's institutional history has contributed to its beer diversity. The Belgian area has experienced a heterogeneous and variable array of institutional regimes over the last millennia. In many cases institutional boarders crossed through the Belgian area. We trace the historical development of many of Belgium's well known beer varieties to specific institutional causes. We also show that the geographic production of important varieties such as Old Brown, Red Brown, Trappist, Lambic, Saison, and Gruitbeer, continues to be influenced by Belgium's institutional past.
\end{abstract}

\section{Introduction}

When one thinks of German or Czech beer, the lager classification comes to mind. England is known for its ales. Ireland is known for production of stout and red ales. While all major beer producing countries produce multiple types of beer today, most are known for one or two specific varieties. Belgium, however, produces diverse assortment of varieties made under different fermentation methods and with a sundry of ingredients (Jackson, 1991). Patroons (1979: 7) writes that, "Just as we call France the 'wine' country [of the world], we could consider Belgium as the 'beer' country. After all, nowhere you will find so many different types of beer." ${ }^{1}$ While Belgian beer continues to win many prestigious international prizes, what the nation is truly known for is

\footnotetext{
${ }^{1}$ This quote is translated from Flemish.
} 
the vast diversity of beer that it produces. Belgium's reputation for beer diversity is not new. In 1851 French brewing engineer Georges Lacambre (1851: 302) noted that many regions within Belgium produced their own distinctive beer giving the small nation the greatest variety of beer in the world. We believe that there is a compelling institutional story behind Belgium's historically strong beer diversity.

Our study boils down to the demonstration of a chain of causality between the following three observations. First, as noted above, there is a strong consensus that the small nation of Belgium has historically produced a highly diverse assortment of beer varieties. Second, many (but not all) of Belgium's beer varieties are today still produced in geographic sub-regions within Belgium. Third, the geographic area that today comprises Belgium - itself only a country since 1830 - experienced a heterogeneous and variable array of institutional regimes over the last millennium.

We examine the development and persistence of the production of several of Belgium's important beer varieties and find that a heterogeneous array of institutions that affected preindependent Belgium, which regulated ingredients or production processes, had important influences on well-known varieties such as Old Brown, Red Brown, Trappist, Lambic, Saison, and Gruitbier. We also find that institutions in post-independent Belgium affected beer diversity. For example the 1918 Vandervelde Act, which did not allow spirits to be sold in pubs until the end of 1983, influenced the development of key high-alcohol volume varieties such as Belgium's wellknown Dubbles and Tripels. Our findings suggest that Belgium's unique beer diversity can be explained by the diverse institutional history of the areas that comprise the nation. 


\section{Theoretical Background: New Institutional Economics and Path Dependence}

North $(1990,3)$ defines institutions as "humanly devised constraints that shape interaction [and] structure incentives in human exchange." Institutions can exist in the form of legal regulations or via social customs, traditions, or conventions. Voigt (2013) breaks institutions into categories based upon who does the sanctioning-"external" institutions are those whereby the state sanctions, whereas "internal" institutions pertain to those where members of society sanction. ${ }^{2}$ Engel and Webber (2007) develop a framework whereby the institutional background (internal or external) can affect human behavior at each step of the decision-making model.

The general conclusion of New Intuitional Economics (NIE) is that institutions matter with respect to driving economic outcomes in the geographic regions that they affect. For example, Olson (1996) contends that nations with high-quality institutions are better able to reach their economic potential than otherwise. In empirical examinations of this hypotheses, Hall and Jones (1999) show that the quality of a nation's institutional framework is strongly correlated with output per worker across 127 countries. Similarly, Rodrik et al. (2004) show that the quality of institutions trumps other factors such as geography and trade when it comes to determining income levels around the world. ${ }^{3}$ Greif (2006) explores institutional formation in the late medieval era and shows why many historic institutions persist and continue to affect economic outcomes in the modern era. Such studies suggest that institutional framework goes a long way toward explaining the

\footnotetext{
${ }^{2}$ Internal institutions are further broken into four separate types depending upon the specific nature and degree of enforcement by society. Type-one internal institutions include societal conventions while type-two includes ethical rules, such as the 10 Commandments. Type-three internal institutions include customs and type-four includes formal private rules, such as rules that might be developed by a trade association or a group of merchants.

${ }^{3}$ However, critics such as Glaeser et al. (2004) argue that the development of good institutions such as property rights and democracy may not cause, but rather be a consequence of, economic growth.
} 
economic development of a geographic location over time. We employ these aspects of NIE in the context of beer production in the Belgian area.

The NIE framework also highlights the importance of "path dependence"- the theory that temporally remote events influence current economic activity because the old methods become entrenched or locked in. Thus economic activity may continue in a certain manner even long after the reason (institutional or otherwise) for its development in this manner has ceased. Generally, to show that an outcome was the result of path dependence one must demonstrate (1) that multiple paths were possible (i.e. specify a counterfactual), (2) that historical events influenced which path was followed, and (3) that society remained on that path because of the presence of a selfreinforcing mechanism that makes deviations from the path costly (Arthur, 1988, 1989). For example, the presence of network externalities, whereby the usefulness of an item or process rises as more people adopt it, could create a self-reinforcing mechanism. Likewise Levi (1997: 28) notes that path dependencies can develop when the "entrenchment of certain institutional arrangements obstruct an easy reversal of the initial choice." North (1993: 3) contends that path dependent outcomes may persist because change may be resisted by actors who have "a crucial stake in perpetuating the system." Heikkila (2011) extends the model of path dependence to show that current decisions can be shaped by knowledge of the past. Thus information about the historical path, and not just the path itself, is an important determinant of behavior.

While the concept of path dependency has its critics (for example Liebowitz and Margolis, 1990, 1995), it has been suggested to have affected several economic outcomes. For example, Hansen and Hansen (2007) show that debtor-friendly bankruptcy law arose in the United States in the late $19^{\text {th }}$ and early $20^{\text {th }}$ centuries as a result of a path dependent process. Puffert (2002) demonstrates the role that path dependence has played in railway track gauges around the world. 
Cowan (1990) shows that light water reactors emerged as the dominant technology in nuclear power, and even though superior technologies have been developed they have remained dominant via path dependency.

More recently, following Garud and Karnoe (2001), scholars have emphasized the role economic actors play in shaping their environment - thus rather than treating the process of lockin as a random event or historical accident, it is viewed endogenously via the concepts of "path creation" and "mindful deviation." In this model actors can mindfully direct and shape practices, laws, or other institutions which then create locked-in paths. To illustrate, Stack and Gartland (2005) note that large high-cost breweries gained market share in the postwar United States due to laws that favored this scenario. While an analysis relying on path dependence would highlight this less efficient outcome becoming locked in, Stack and Gartland (2005: 428) employ path creation to show how large breweries mindfully shaped the competitive environment after repeal of Prohibition to bring about "the curious result of higher cost producers gaining greater and greater market share."

Stack, Gartland, and Keane (2016) note that path dependency need not be caused by technological lock-in — as is generally posited in case studies of path dependence — but could instead arise from what they call "behavioral lock-in." Once a region's consumers have become comfortable with a specific practice or taste, they will be less likely to try new alternatives. Thus, consumers often develop deep-seated behavioral roots that cause them to cling to their native foods or drinks. As this relates to beer, the authors argue that consumers in many countries are extremely loyal to their traditional styles and that this behavioral lock-in can explain why the vast majority of beer today is consumed within the country that it was made. They also employ behavioral lockin to explain why the internationalization strategies of many large brands have failed in recent 
decades. In a similar vein, Dighe (2017) notes that regional beer production often becomes locked in by the "customs and tastes that stabilized over the course of centuries."4 We will show that the insights from these studies can be applied to the case of Belgian beer.

\section{The Diversity and Spatial Production of Belgium Beer}

We acknowledge that many industrialized countries have experienced a boom in craft brewing over the last two decades and this has led to a worldwide beer-diversity revolution (Garavaglia and Swinnen, 2018). ${ }^{5}$ Although other nations have begun to catch up to Belgium in terms of diversity, understanding the underlying roots of Belgium's historic diversity remains important. In fact, its native beer varieties have had a large influence on the growing beer diversity brought by the craft brewing movement in many countries today. ${ }^{6}$

Belgium has a very strong and historic beer culture. While it is the $7^{\text {th }}$ largest beer producer in the European Union by volume, Belgium ranks first in the world in production per capita (Belgische Brouwers, 2014). In 2015, Belgium had 199 breweries, producing nearly 2,500 different beer products. ${ }^{7}$ Its largest producer, Anheuser Busch InBev, produces around 57 percent of Belgian output. Belgium's second largest producer, Heineken (which owns the Affligem Brewery) has 12 percent market share. The next three largest producers include Haacht (8 percent),

\footnotetext{
${ }^{4}$ Several studies have analyzed the persistence of private standards and public regulations affecting food variety and quality. See for example, Meloni and Swinnen (2013, 2016a, 2016b, 2018), Swinnen (2017) and Deconinck, Poelmans and Swinnen (2016).

${ }^{5}$ In this respect Garavaglia and Swinnen (2018: viii) claim that the US is today is "the world's largest and arguably most dynamic craft beer scene."

${ }^{6}$ Of course some of the newly brewed Belgian beers today have likewise been influenced by the recent development in other nations. For instance, recently new Belgian beers emerged using more hops, following the example of American craft beers. Also American style IPAs' have recently been copied by Belgian brewers (Alworth, 2015; Poelmans and Swinnen, 2018).

${ }^{7}$ Authors' calculation is based on data from www.zythos.be, www.bierebel.com, the official websites of several Belgian brewing companies, and the website of the Belgian Brewers Association (Belgische Brouwers) www.belgianbrewers.be.
} 
Duvel-Moortgat (around 5 percent) and Palm (4 percent). ${ }^{8}$ None of the other 194 brewing companies had more than 3 percent of the market and thus the vast majority of Belgian producers are small-scale breweries. Sixty-two percent of the beer Belgium produces is exported.

Webb and Beaumont (2012: 52) note that Belgium produces "over 400 discernably different styles of beer." While it is beyond the scope of this paper to list every distinct variety of Belgian beer, the following paragraph provides the reader an overview of the 10 broad categories of Belgian beer employed by several beer institutions (such as the Belgian Brewers and Zythos)— Lager, Lambic, Trappist, Abbey, Witbier, Saison, Strong Blonde, Old Brown, Red Brown, and a tenth category that includes many Special/Regional/Theme beers.

Lager beer, of which Pilsner is a subcategory, is brewed under bottom fermentation (Stella Artois is certainly the best known brand of these from Belgium). ${ }^{9}$ Lambic, and its associated subcategories of Gueuze, Faro, and Fruit beers, are brewed with spontaneous fermentation, as opposed to adding brewer's yeast. Top-fermented Trappist beer must be made within the walls of a Trappist monastery or in the vicinity of a monastery, either by monks or under the direct supervision of monks. Abbey beer is brewed in a similar style to Trappist beer, but its producers do not have to abide by the strict production rules of the Trappist brewers. ${ }^{10}$ Witbier, often called "Belgian White" in other countries, is an unfiltered, cloudy wheat beer, which often has extra barley added. Saison (Season) beer is both heavily hopped and strongly seasoned with herbs, which provides this variety a unique flavor profile. Belgian Strong Blonde beer (such as Duvel) is a lighter version of a pale ale similar to those brewed in England. Old Brown is an acidified beer that is

\footnotetext{
${ }^{8}$ The company websites; The Annual Reports of the different brewers, in 2015 and AB InBev Belgium, 2014.

${ }^{9}$ Also see Vanrafelghem, 2013: 226 and Deweer, 2015: 1603-1606 for an overview of Belgian beer varieties.

${ }^{10}$ To be categorized as an Acknowledged Belgian Abbey Beer the brewery has to have a link with an existing or former abbey or the brewery must pay royalties for charitable or cultural purposes to the Abbey or to a foundation that is connected to the former Abbey.
} 
very lightly hopped, instead relying upon lactic and acetic acids for preservation. It is brewed under mixed fermentation. Red Brown is produced in methods that are similar to Old Brown, but it employs red malt and has a strong fruit flavor (plum, raspberry, raisin, or prune). Finally, with respect to the $10^{\text {th }}$ category, Belgium produces numerous unique varieties that are broadly categorized as Regional, Special, Christmas, or Theme. Many of these key varieties have been copied by brewers in other countries, particularly since the craft beer movement took off, who produce their own variations of Belgian styles such as Molsen Coors "Blue Moon" (which is a Belgian Witbier), the "Abbey Dubbel" from New Jersey's Flying Fish Brewing Company, or the "Transatlantique Kriek Sour Ale" (a beer which would fit under the Lambic category) produced by the New Belgian Brewing Company in Fort Collins, Colorado.

\section{The Spatial Distribution of Beer Production in Belgium Today}

Many of Belgium's historic and unique beer varieties are largely produced in geographic subregions within Belgium. The best way to demonstrate this geographic production is via maps that show the precise location of producers today. We create these maps using ArcGIS Pro whereby each brewery is added as a geo-referenced feature. ${ }^{11}$ From the ten above-mentioned broad categories of beer varieties in Belgium we are effectively able to plot only eight of them as Regional (which also includes Special/Christmas/Theme beers) and Strong Blonde beer varieties are generally categorized under one of the remaining eight mapped varieties.

Belgium's land area is only around 30,000 square kilometers (12,000 square miles), which is just smaller than the state of Maryland in the United States. The country can be divided into

\footnotetext{
${ }^{11}$ The calculation of the number of breweries, the types of beers they brew, and the street addresses are assembled from www.zythos.be, www.bierebel.com, the official websites of the different Belgian brewing companies, and the website of the Belgian Brewers Association.
} 
three regions-Wallonia, in the south, which speaks French and German, Flanders in the north, which speaks Dutch, and the Brussels Capital Region, which is officially bilingual (Dutch and French) — and into 10 provinces. Figure 1 shows the 2016 location of the 12 producers of Old Brown (Oud Bruin) beer. Some producers make multiple brands of this variety. For example, the northeastern-most dot in East Flanders represents the brewery De Proefbrouwerij which produces two Old Brown beers "Totentrekker" and "Zoetzuur." Figure 2 shows the location of the 10 producers of Red Brown beer. Note that in the cases of both Old and Red Brown, production today is almost exclusively west of the Scheldt River, in the Northwest part of the country. Some of the breweries producing these varieties are several centuries old, while others are simply following the longstanding brewing traditions of the region.

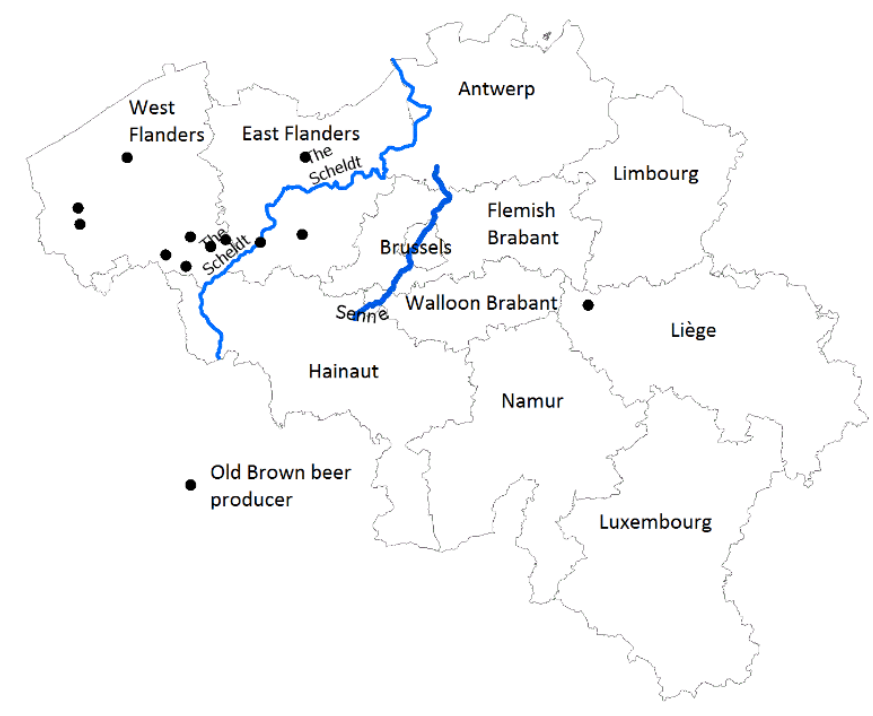

Figure 1

Location of Old Brown Beer Producers in 2016 


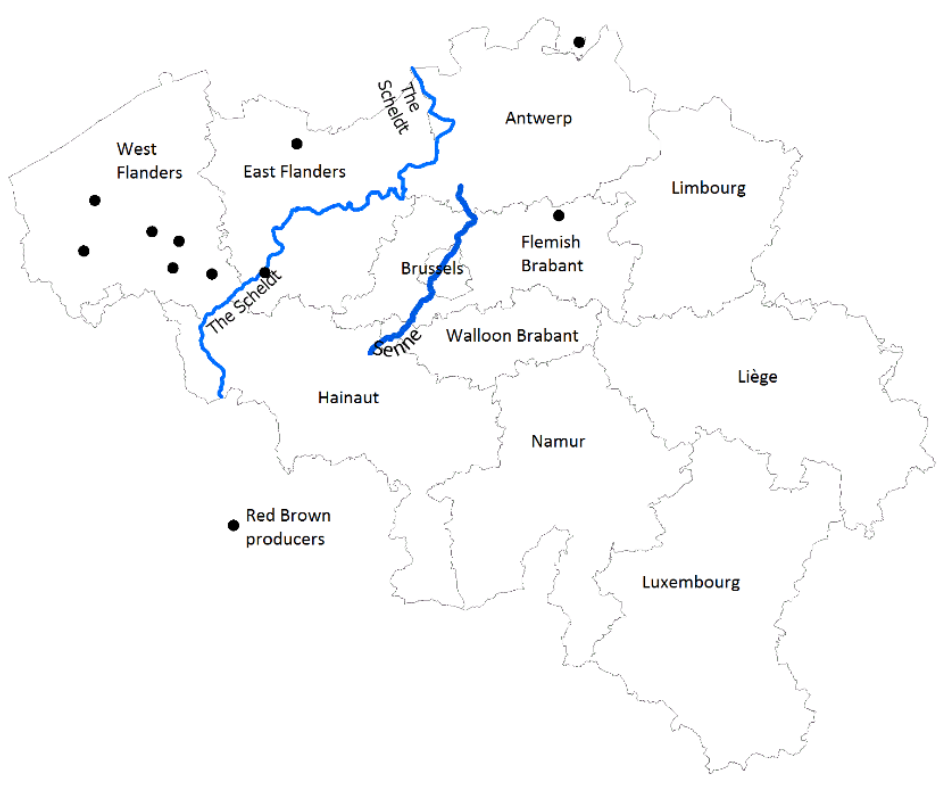

Figure 2

Location of Red Brown Beer Producers in $2016^{12}$

Figure 3 shows the location of the 22 producers of Saison beer. It is notable that a large proportion of producers are in or near the province of Hainaut. Moreover, 77 percent of them are situated in Wallonia, the French speaking part of the country. Figure 4 plots the location of the six Trappist breweries in Belgium today-all of these are located near the national border. The location of the 16 producers of Spontaneous Fermentation Beer are shown in Figure 5. With just 3 exceptions, all these breweries are located with 15 kilometers (9 miles) of the Senne River, in the Brussels Capital Region, Flemish Brabant, and Walloon Brabant.

\footnotetext{
${ }^{12}$ The dot on top of Figure 2, outside of the borders of Belgium is the brewery "De dochter van de Korenaar" in the village Baarle-Hertog, which is a Belgian enclave in the Netherlands (Degrande 2009: 142).
} 


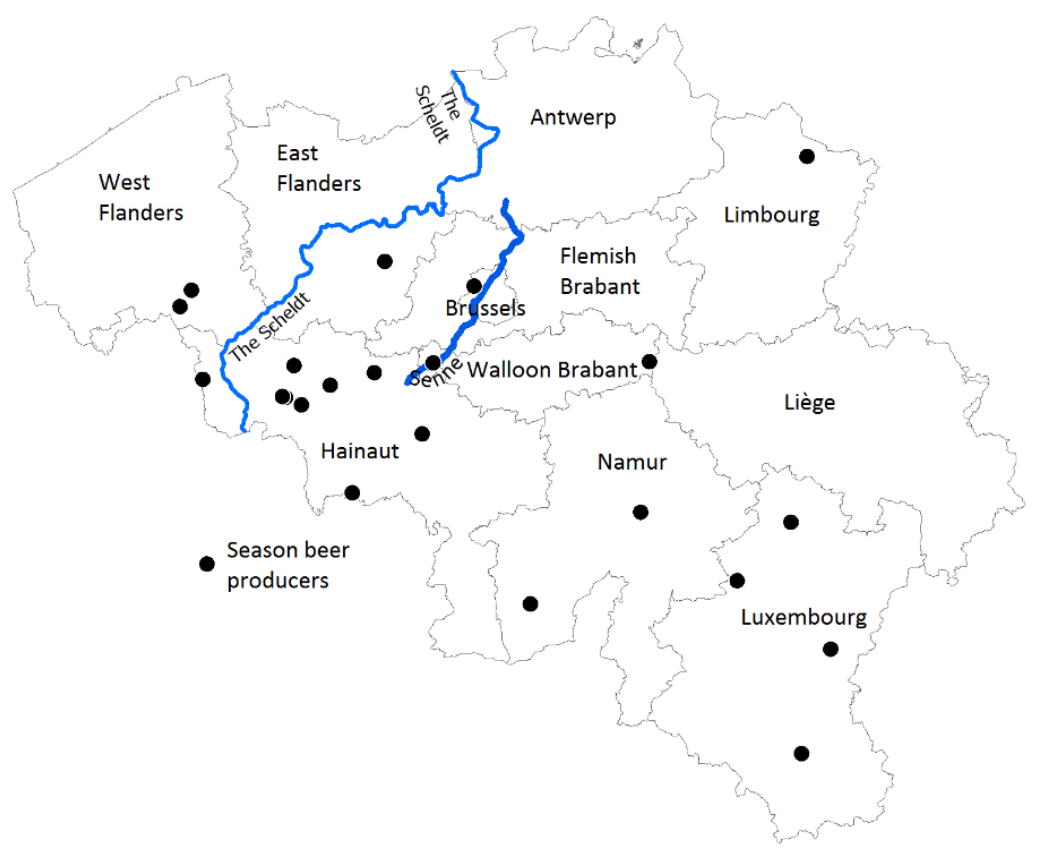

Figure 3

Location of Season (Saison) Beer Producers in 2016

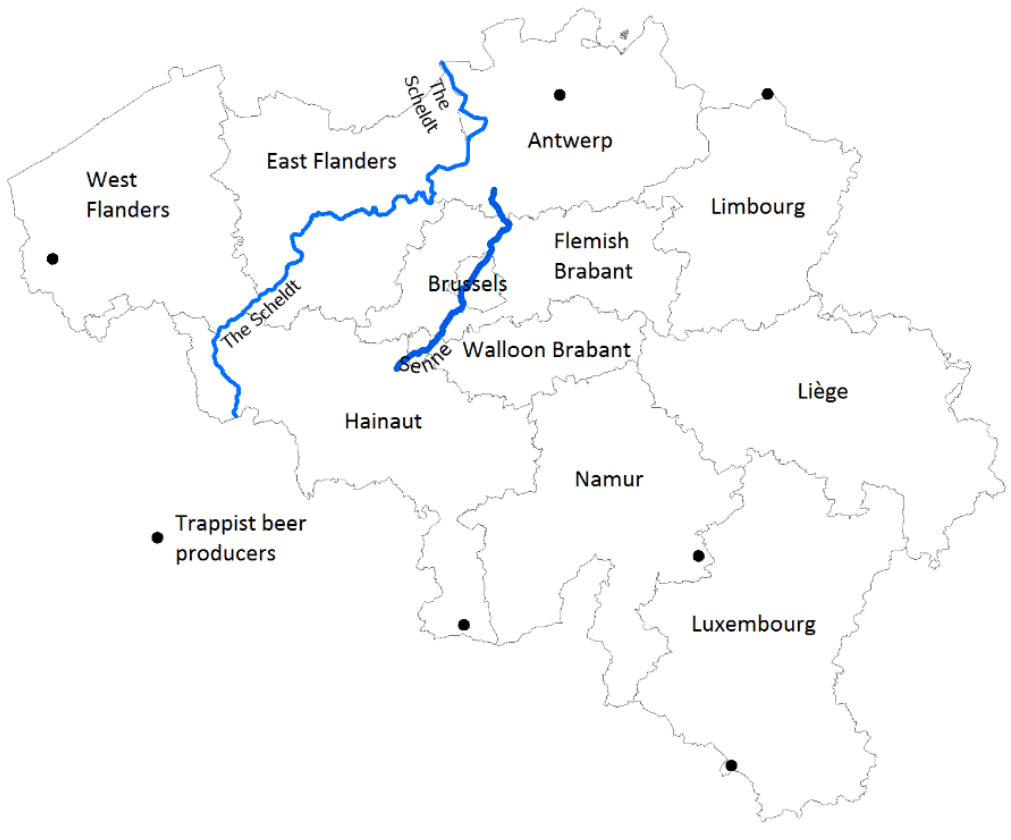

Figure 4

Location of Trappist Beer Producers in 2016 


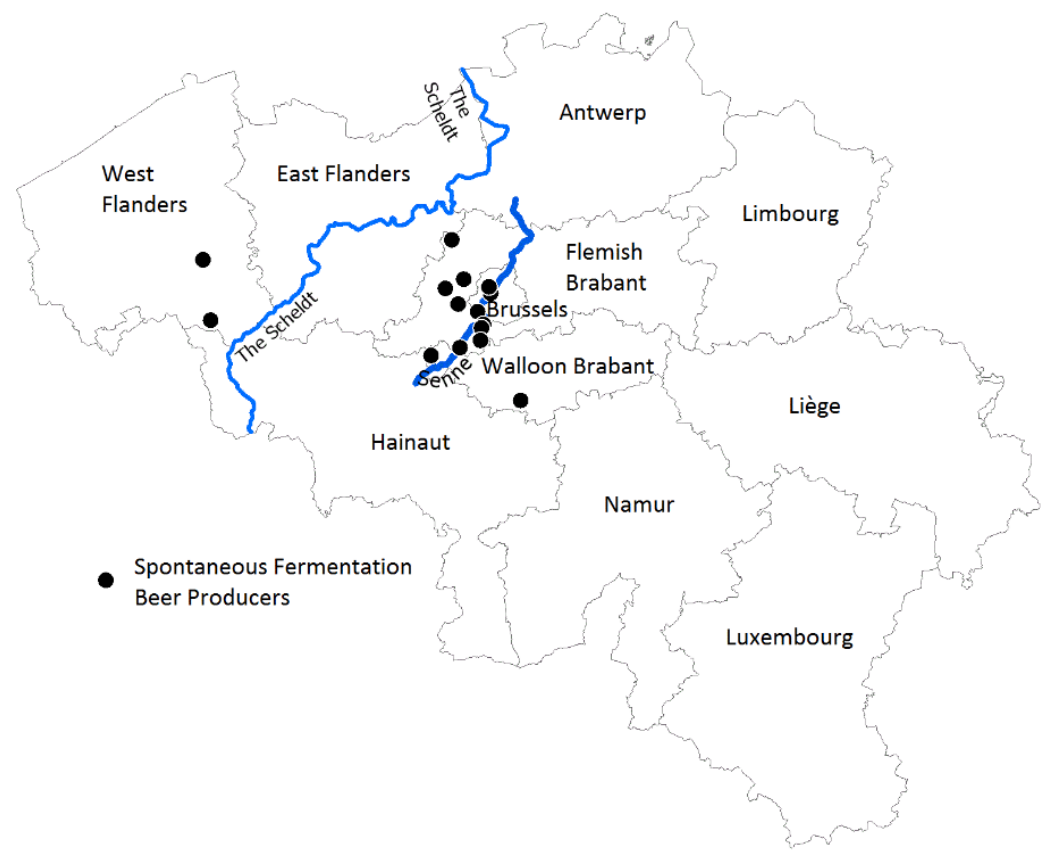

Figure 5

Location of Spontaneous Fermentation Beer Producers in 2016

Figures 6, 7, and 8 show the geographic dispersion of Pilsner, Abbey, and Witbier, respectively. In contrast to the beer varieties reported in Figures 1 through 5, brewers of these three varieties are dispersed throughout all of Belgium. Each of these varieties are produced in every one of Belgium's 10 provinces (the one exception is that no Abbey beer is produced in the Luxembourg province). As we will explain later, there are compelling institutional reasons why the production of five of the eight varieties is geographically specific and why production of the remaining three is not. 


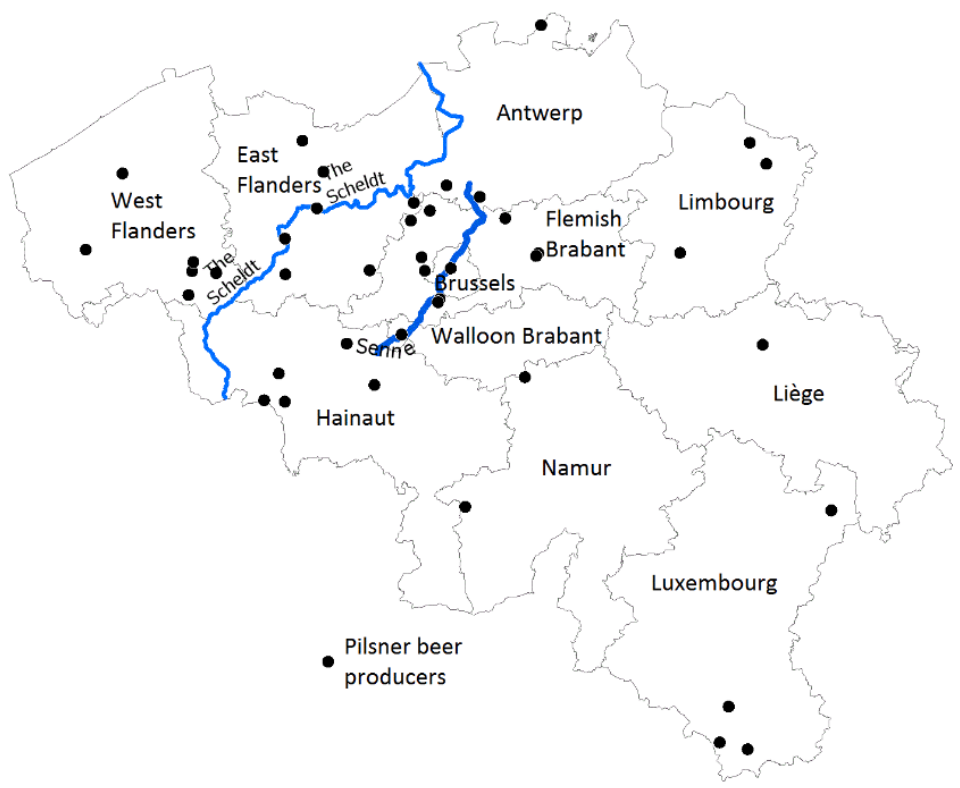

Figure 6

Location of Pilsner Beer Producers in 2016

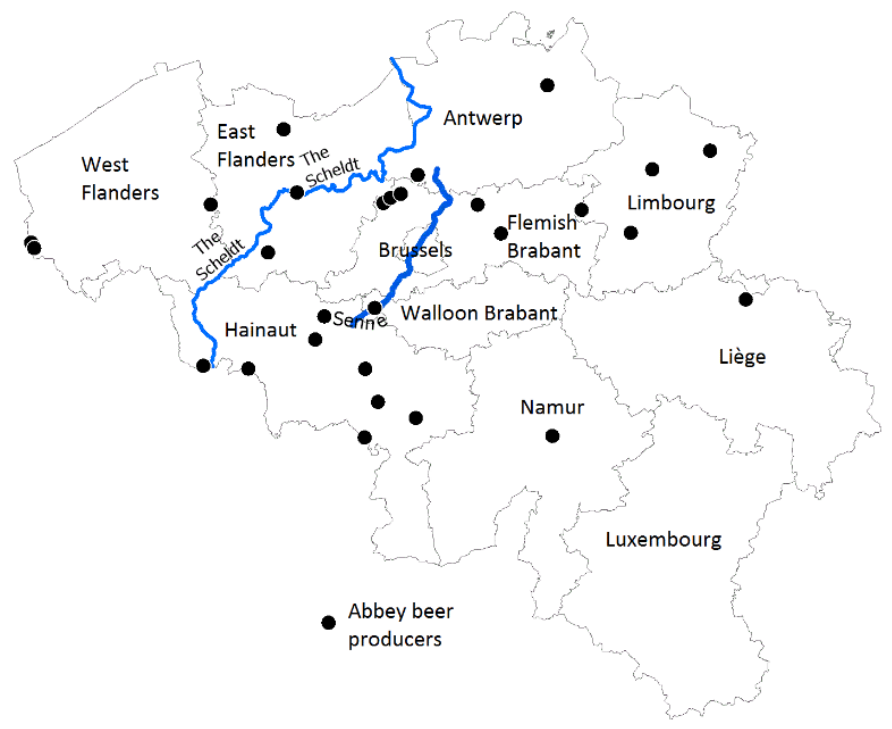

Figure 7

Location of Abbey Beer Producers in 2016 


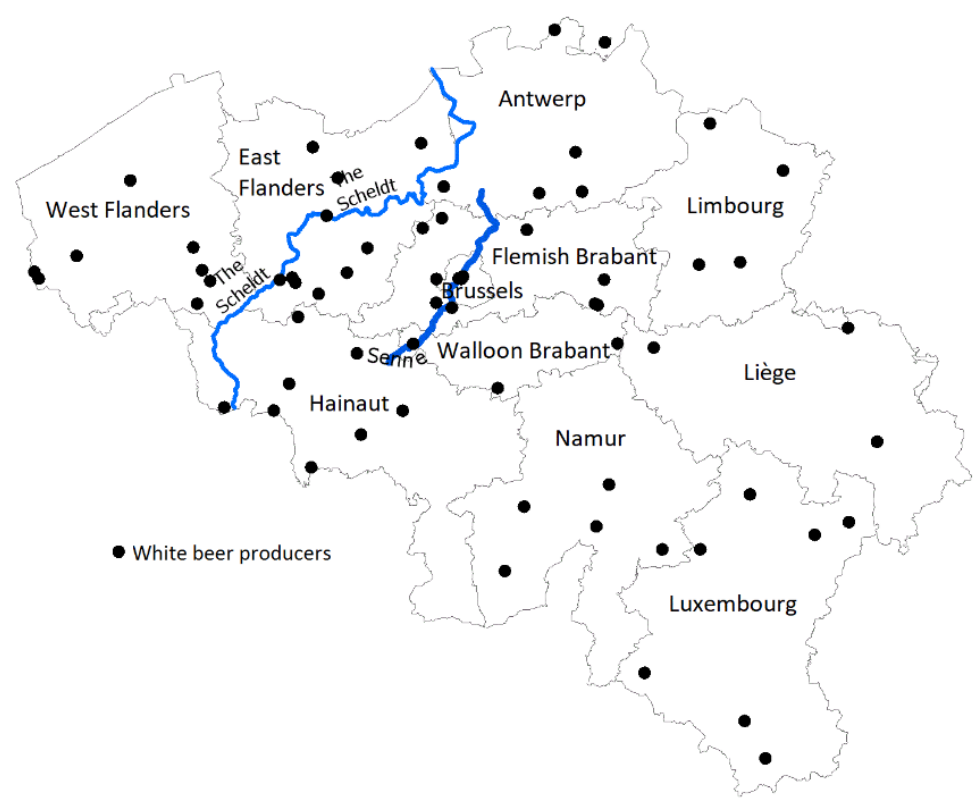

Figure 8

Location of Belgian White (Witbeer) Producers in 2016

\section{The Belgian Area's Institutional History Prior to 1830 and its Effect on Beer}

The area that today comprises Belgium-itself only a country since 1830 —experienced a geographically heterogeneous array of institutional regimes over the last millennium. For the interested readers, the online appendix details the long and complex institutional history of the area between 843 and Belgian independence. ${ }^{13}$ To make a long story short, control of the areaor various parts of it - changed hands many times between the ruling kingdoms of Europe throughout these thousand years. Importantly, in many cases borders between ruling families cut through present day Belgium.

\footnotetext{
${ }^{13}$ This can be accessed via Jason E. Taylor's google sites webpage or through the following link. https://docs.google.com/viewer?a=v\&pid=sites\&srcid=ZGVmYXVsdGRvbWFpbnx0YXlsbzJqZXxneDo3YWIwNz c2ZTQxNjljOGJi
} 
Institutions can affect beer production through the presence of laws specifying what ingredients or production processes must be used. In fact, we will show that some Belgian beer varieties can be traced to such local laws. In other cases, we will show that Belgian varieties developed because institutions slowed the adoption of key ingredients such as hops, and thus local producers had to rely on alternatives. The area that is today Belgium has been the subject of territorial dispute and has changed hands many times in the last millennium. Olson (1982) suggests that such institutional instability creates more dynamic (and better) economic outcomes since there is less of a chance for interest groups to develop and succeed in collective action that would hinder development. The lack of stable "centralized" control has allowed Belgian brewers the freedom to engage in heterogeneous beer production methods to a far greater extent than in many other regions where pervasive regulations like the Reinheitsgebot, which for over 500 years has allowed only barley, hops and pure water to be employed in Bavarian beer. ${ }^{14}$

\section{Institutions Affecting the Speed and Extent of Adoption of Hops in Beer Production}

Hops are a key staple in the production of beer today. Prior to the use of hops brewers generally employed "gruit" to flavor and preserve beer against spoilage. The contents of gruit varied from place to place, but its primary component was bog myrtle. It also generally included some mixture of herbs and spices such as aniseed, bay leaf, cinnamon, clove, coriander, juniper berry, orange and lemon peels, resin, rosemary, saffron, sage, and yarrow. The Emperor, as owner of the

\footnotetext{
${ }^{14}$ The Reinheitsgebot was first implemented in Munich, Bavaria in 1487 and then extended to cover the whole of Bavaria in 1516. Yeast was added to the list of allowable ingredients in 1847. This law continues to affect German brewing today, although some aspects were relaxed in 1987 by the rules of the European Union. Degrande (2009: 104) and Verdonck and De Raedemaeker (2016: 48) claim that the Reinheitsgebot obliged the parts of current-day Belgium that were then part of the Holy Roman Empire to use hops in their beer. However, the Reinheitsgebot initially only covered Bavaria and although other regions, such as Baden in 1896 and Würtemberg in 1900, adopted this obligation it only become mandatory for the whole of Germany in 1906, when no part of modern day Belgium was part of Germany.
} 
uncultivated land where these ingredients grew, treated the monopoly on the gruit as a royal right. This right could be extended to bishops, local noblemen, or other town leaders who would then produce and sell their gruit, which often contained secret combinations of different herbs, to local brewers. ${ }^{15}$ Since brewing without gruit was illegal, those given this right could make large profits from the ability to produce and sell gruit to captive buyers.

The use of hops, whose bitterness helped balance the sweetness of malt and also acted as a superior preservative to gruit, was a major innovation in the late Middle Ages. However Unger (2004: 53-57) and Poelmans and Swinnen (2011a, 1999) note that for several reasons-technical, cultural, and commercial - it took decades, or in some regions centuries, for hops to become widely used. Trade-oriented German villages such as Bremen, Wismar, Rostock, and Hamburg, saw the strong economic advantage of producing beer with a longer shelf life and thus the widespread adoption of hops generally began in these areas in the $13^{\text {th }}$ century. To maintain gruit revenues, rulers in the Low Countries initially prohibited the domestic production of hopped beer and heavily taxed imports from 'Germany.' However, Unger (2001: 74-75) notes that in 1321 the count of Holland acquiesced to brewers' demands and allowed hops to be employed in beer production. For the next two and a half centuries taxes from both gruit and hops were collected in Holland. ${ }^{16}$

In the Southern Low Countries, which largely encompasses current-day Belgium, however, the adoption of hops was much slower. Degrande (2009) and Verdonck and De Raedemaeker (2016) highlight the importance of the 1364 Novus Modus Fermentandi Cerevisiam, which translates to "New Method to Brew Beer." This proclamation from Holy Roman Emperor Charles

\footnotetext{
15 Poelmans and Swinnen (2011a)

${ }^{16}$ Hornsey (2003: 535) notes that the city of Amsterdam purchased the right to collect taxes on gruit from Phillip II of Spain in 1559 - this was the last recorded transfer of a "gruitrecht" in that country.
} 
IV helped clear the way for the quicker adoption of hops as it permitted local rulers to tax hops rather than relying only on the sale of gruit for revenues. ${ }^{17}$ Around 75 percent of present-day Belgium — specifically land east of the Scheldt River — was a part of the Holy Roman Empire at that time. Hence Brabant, located east of the Scheldt, was faced with an institutional regime in which hops were legally embraced much faster than they were in Crown Flanders, west of the river, and in Imperial Flanders on the east bank of the river ${ }^{18}$, which were both under French rule and hence not affected by the Novus Modus Fermentandi Cerevisiam.

Unger (2004: 92) notes that in the first half of the $15^{\text {th }}$ century the Flemish cities of Bruges, Ghent, and Ypres, which were not affected by the Novus, fought vigorously to keep out imported hopped beers by increasing the taxes on these imports. In the parts of present day Belgium that were affected by the Novus, hops began to be employed. In Leuven (Brabant) hops began to be used almost immediately after the Novus and Swinnen and Briski (2017: 21) note that Leuven brewers had switched completely to hops by 1436. The use of hops began in Mechelen and Vilvoorde around 1370, in Lier around 1400, and in Antwerp in 1408. ${ }^{19}$ Thanks to the stabilizing quality of hops, beer made in Brussels, Antwerp, and Leuven was transported around the region and by 1450 Leuven had become an important center of brewing. Of course it remains so today, hosting the headquarters of the world's largest brewer, AB InBev.

Because of these differing institutional conditions, the use of hops remained less pronounced in Flanders than in other parts of Belgium for centuries - even long after hops were

\footnotetext{
${ }^{17}$ The text of the Novus Modus Fermentandi Cerevisiam translates as follows: "In the past thirty or forty years a new method of fermenting beer, namely by adding an herb called "humulus" or "hop," is used by the citizens in such a manner that the bishop of Utrecht is suffering a large diminution in the revenues he obtained from distributing gruit." The proclamation went on to give explicit permission for the bishop of Liège and Utrecht to levy a tax on domestically produced hopped beer. See Beckmann (1814) for more details about this proclamation.

${ }^{18}$ Imperial Flanders was given as a fief by the Holy Roman Emperor to the Counts of Flanders. So, although Imperial Flanders is geographically located east of the river it was part of Flanders. So this 'Imperial Flanders' was an exception to the Scheldt as 'dividing line'.

${ }^{19}$ Unger (2004: 94).
} 
allowed there. This can be seen via the subsequent development of beer types where brewers employed alternative ways to preserve beer rather than simply adding hops. Old Brown beer is an example of a beer variety that rather than being hop-centric is highly acidified. Production of Old Brown beer can be dated back to at least 1545 in the village of Oudenaarde. ${ }^{20}$ As shown earlier production of Old Brown beer (and the closely related Red Brown beer) takes place today where it has historically always been-in areas west of the Scheldt River where the Novus of 1364 had no effect.

\section{Village-Specific Institutional Regimes and their Effect on Beer Diversity}

Beer historians have given the Bavarian/German Reinheitsgebot of 1516 major attention because of its large geographic scope, however, village-specific laws regulating beer ingredients date at least as far back as 1143 when Augsburg passed the world's first "purity law" specifying what ingredients could be employed in beer. ${ }^{21}$ Throughout the Middle Ages authorities all across Europe employed Reinheitsgebot-like restrictions that outlined what methods and ingredients could be used in beer production. When these affected large regions-as was the case of the Reinheitsgebot - they made for less diverse beer offering. In the region that is modern day Belgium, however, such beer regulations were both heterogeneous and village-specific so they actually promoted beer diversity.

Village-specific regulations on brewing were primarily enacted to help local governments fight tax avoidance. This was important since generally around half of Belgian villages' revenues came from beer taxes in the $15^{\text {th }}$ and $16^{\text {th }}$ centuries - a contemporary Flemish expression noted

\footnotetext{
${ }^{20}$ Hops were used in beer production in Oudenaarde by the mid-16th century, but gruit beer was also still being made as the full transition to hops was not yet complete.

${ }^{21}$ Deutscherbrauer-bund e.V. (2015).
} 
that "a city treasury floats on beer." 22 If, for example, taxes were based upon the use of barley, brewers may reduce their tax burden by employing other grains. ${ }^{23}$ Some villages imposed higher beer taxes as alcohol content rose. As there was no way to accurately assess the volume of alcohol in beer, however, brewers sometimes classified their beer as having lower alcohol content than it truly had. To combat such attempts at tax avoidance, villages created strict rules specifying who could produce beer, what ingredients could be used, and what production processes could be employed (Unger, 2001). This may be viewed an application of Yandle's (1983) and Smith and Yandle's (2014) "bootleggers and the Baptists" story. Yandle notes that regulations are more likely to emerge and endure when both the "bootleggers" who seek the private benefits from the regulation, and the "Baptists," who wish to serve the public interest, support them. In this case the existing local brewers had incentives to lobby their rulers to standardize beer recipes as a means of limiting potential competition from new differentiated products. The rulers likewise had incentives to keep beer standardized since it helped them avoid tax evasion.

To illustrate, regulations regarding the production of Old Brown beer in Oudenaarde and Red Brown beer in Roeselare specified how long the malt was to be dried and how long the wort had to be cooked. ${ }^{24}$ Likewise, in Halle, just south of Brussels, a 1559 law stipulated that the mash had to use 300 liters of wheat and 500 liters of barley and oats. ${ }^{25}$ In the city of Namur, a 1606 charter explicitly stated the ingredients that could be used in order to produce bière de Namur. The beer had to be "brewed with only good grain and hops" and "without the addition of any other ingredients, herbs or other illegal substances, that could harm the human body [or] lead to

\footnotetext{
${ }^{22}$ Belgische Brouwers (1997). For instance, in $16^{\text {th }}$ century Oudenaarde the share of beer taxes in the total city's revenue was 43.5 percent, while in the city of Ghent it was 41.3 percent. Cappelle $(2010: 29)$.

${ }^{23}$ Perrier-Robert and Fontaine (1996:25).

${ }^{24}$ Cappelle (2010: 69).

${ }^{25}$ Degrande (2009: 55-56).
} 
blasphemy." ${ }^{26}$ Today, Lambic-style beers such as Kriek Lambic and Gueuze are made in Halle using a mash that follows these same proportions while Old Brown beer in Oudenaarde and Red Brown beer in Roeselare is likewise produced with methods very similar to those that were mandated by law in the past.

Similarly, a decree in 1615 in the small village of Hoegaarden (in Flemish Brabant) mentioned both rules on who could brew and on the ingredients of the beer. Brewers in this village had to be Catholic and had to "pledge allegiance to the bishop and his successors." ${ }^{27}$ With regard to the ingredients that could be used in the brew, the decree specified the following proportions" 4 parts of barley malt, 4 parts of wheat and 2 parts of oats." ${ }^{28}$ Furthermore, beer in Hoegaarden could only be made with the water from the local river. Interestingly, in 2005 production of the well-known Hoegaarden beer was moved away from the village of Hoegaarden to the city of Jupille in the Walloon province. In 2007, however, AB InBev moved the beer's production back to the original cite in the village of Hoegaarden because it felt that the change in water (the main ingredient in beer) had altered the flavor profile too much. ${ }^{29}$

The revitalization of the production of Belgian beer made with gruit over the last decade provides another example of past village-specific institutions affecting beer production today. In the Middle Ages villages generally employed unique combinations of herbs and spices in their gruit so that each area produced its own distinctive beer. Since brewers were obliged to buy gruit only from their local rulers the geographic diversity of gruit made it difficult to cheat by buying gruit from a nearby town. This limited competition and kept gruit prices high. Belgian brewers

\footnotetext{
${ }^{26}$ Anonymous (10 July 1908) : 559.

${ }^{27}$ Anonymous (7 May 1909) : 490.

28 Anonymous (7 May 1909) : 492

${ }^{29}$ Degrande (2009: 72-74).
} 
who produce "gruitbeer" today generally employ their village's specific recipe from the past. Examples include the breweries Gageleer from Wommelgem, Gruut Stadsbrouwerij from Ghent, and De Gouden Boom from Bruges.

\section{Institutions since Belgian Independence in 1830 and Their Effect on Beer}

The prior section suggests that the institutional heterogeneity that the Belgian area experienced before it became a country in 1830 promoted diversity in beer production both by affecting the speed with which hops were employed and via heterogeneous village-specific regulations affecting the ingredients and production processes that could be employed in beer. Next we address how institutions that impacted the whole of post-independent Belgium helped maintain the locality and variety of Belgian beers. We also show how they led to the creation and proliferation of other beer types.

\section{Monastic Brewing}

A case could be made that the most famous Belgian beer variety today is Trappist beer. Monastic brewing has occurred in the area that comprises Belgium since the Middle Ages, but the specific Trappist order was founded in the 1660s. When France took control of the Belgian area in the 1790s, corporations, guilds, and monasteries were generally confiscated or destroyed and monastic brewing ceased in the region. However, the Belgian Constitution of 1831 reinstated religious freedom and monasteries were able to return. In 1831, just after the Constitution's enactment, Westvleteren became the first monastery to start brewing Trappist beer. Westmalle (1836), Achel (1846), Chimay (1862), Rochefort (1899) and Orval (1931) followed and today these six producers 
make some of Belgium's most sought-after, award winning, and distinctive beer. ${ }^{30}$ The early decision of independent Belgium to allow monasteries to return played a key factor in the subsequent development of one of Belgium's most renowned beer types.

\section{Belgian Tax Policy and Beer Production in the $19^{\text {th }}$ Century}

In the early to mid- $19^{\text {th }}$ century, the average Belgian brewery was very small, producing around 200,000 liters per year. To provide context in the 1980s the United States defined a "microbrewery" as a brewery producing less than 1.8 million liters per year. Furthermore, rather than bottle and distribute beer, Belgian brewers typically sold beer poured from wooden barrels directly to consumers in its own pub, which was typically adjacent to the brewery. In 1845 there were 3,089 breweries, i.e. one for every 1,500 Belgian citizens. Only 2 percent of these breweries employed steam technology. By 1880, when the use of steam was common in breweries across Europe only a third of Belgian brewers were employing it. Belgium was notably slower to adopt mass production brewing techniques than neighboring countries. ${ }^{31}$ As a result Belgian beer production and consumption remained local and villages generally produced distinctive varieties employing local ingredients and traditional production methods.

Two important institutional factors played a major role in keeping $19^{\text {th }}$ century Belgian beer production so local and artisanal. First, beer taxes in Belgium were tied to the size of the fermentation tubs employed (Van Velsen, 1900: 78). Alworth (2015) notes this tax policy favoured traditional fermentation methods over modern ones and thus brewers had less incentive to switch from traditional methods and styles. Second, until 1860 Belgian villages were allowed to tax not

\footnotetext{
${ }^{30}$ Van Uytven (2007: 251) and Verdonck and De Raedemaeker (2016: 246).

${ }^{31}$ Dejongh (1995: 279) and Peumans (1938: 71).
} 
only the production, but also the transport of beer. ${ }^{32}$ This transport tax also created incentives for local brewers to produce on a small scale for local consumers. ${ }^{33}$ These external institutions kept most Belgian brewers small, local, and tied to their traditional methods rather than encouraging them to modernize and produce for larger markets.

\section{Belgium's Socio-Political Climate: An Internal Institution Affecting Beer Diversity}

Another institutional factor in post-independent Belgium that impacted beer diversity was the nation's socio-political climate. This climate would fall under Voigt's (2013) definition of an internal institution. Because beer was so important, both socially and economically, it was common for the mayor of a city/village to be a brewer-beer quality was viewed as an important way to earn votes. As there were generally two dominant political parties, most villages had at least one Catholic and one Liberal brewer who competed, among other ways, through beer. ${ }^{34}$ This contributed heavily to the fact that by 1900 , the number of Belgian breweries had risen to 3,223in comparison there were 1,816 breweries in the United States, a country with over 300 times the land mass and 11 times the population as Belgium. ${ }^{35}$ Furthermore Belgian breweries in 1900 were producing a diversity of more than 15,000 different beer brands and the nation had 185,036 pubs, or one per every 32 inhabitants. We cannot be sure which way the causality runs-i.e. whether the socio-political climate of politicians competing with beer production drove the diverse beer climate, or alternatively, whether the diverse beer climate drove the socio-political institution of

\footnotetext{
32 Segers and Dejongh (2000: 326, 330).

${ }^{33}$ Deconinck and Swinnen (2016: 231).

34 Tollet (2015: 39). Incidentally, the "Belgische Werkliedenpartij (BWP)," the predecessor of the current Flemish and Walloon socialist parties was not established until 1885.

${ }^{35}$ Brewery numbers are from Hornsey (2003: 618), Patroons (1979: 18), and Stack (2000: 49).
} 
politicians competing through beer. In any case, the importance of beer in the $19^{\text {th }}$ century Belgian democratic process impacted that nation's beer diversity.

\section{The Vandervelde Act Leading to a Proliferation of High Alcohol Beer}

Belgium today is also widely known for its production of high-alcohol beer. So-called Belgian Dubbels generally have around double the alcohol content of what most beer traditionally had (i.e. around 7 percent). Belgian Tripels generally go even higher with alcohol percentages that are typically 9 to 11 percent. The proliferation of these beer varieties can be traced back to an institutional change from Belgium's Prohibition movement. In Belgium, spirits were viewed by Temperance forces as the key villain. Hence the Vandervelde Act of 1918 banned the production, export, import, transport, purchase, or sale of all distilled spirits, however, it permitted beer up to 5 percent alcohol by volume (ABV) as well as wine up to 15 percent ABV. In 1919, the ABV cap was lifted on beer, and spirits were allowed to be purchased, but only in large quantities (minimum of two liters) and only for off-premises consumption-importantly, spirits could not be sold in restaurants or pubs. ${ }^{36}$ This act was in effect until 1983.

With spirits off the menu at the pub, high-alcohol beers were developed as an alternative. ${ }^{37}$ For instance, in 1921 the Westmalle monastery started to produce the Westmalle Dubbel (7 percent ABV) and in 1923, the Moortgat brewery introduced Victory Ale, which would later become Duvel (8.5 percent $\mathrm{ABV}$ ). In response to the popularity of these high-alcohol beers, brewers made still higher alcohol products. In 1933, Westmalle released a 9.5 percent ABV beer under the name Superbier. It later renamed the brew Westmalle Tripel and many other brewers subsequently

\footnotetext{
${ }^{36}$ Most laborers did not earn enough to be able to buy two liters at once. Hence, the law was aimed at limiting their consumption of spirits.

${ }^{37}$ Perrier-Robert and Fontaine (1996) and Scholliers (1996: 186-187).
} 
produced Tripels such as Rochefort 10 (10 percent ABV), Westvleteren 12 (10.2 percent ABV), and Kasteelbier Tripel (11 percent ABV). These are amongst the most well-known and Belgian beers today and they were created as a direct result of the Vandervelde Act.

\section{Path Dependence: Brewing Today Based on Brewing in the Past}

We contend that a heterogeneous set of institutional regimes helped create a beer environment in Belgium that was acknowledged to be the most diverse in the world in 1851, and one that continues to be described as such by contemporary sources. But the institutional story is not complete without a discussion of path dependence - the notion that temporally remote events affect current economic activity because the old methods have become entrenched either through technological or behavioral lock-in.

Poelmans and Swinnen (2011b) highlight several beer-related scientific discoveries that transformed the beer industry worldwide between the $18^{\text {th }}$ and $20^{\text {th }}$ centuries. Among these are increased knowledge about the function and composition of yeast, the improvement of the steam engine, advances in refrigeration techniques, new methods to seal beer bottles, and the introduction of metal cans. Despite these advancements, many Belgian breweries have remained faithful to the fermentation methods and ingredients they have employed for centuries. For example, brewers of Lambic beer continue to employ the naturally occurring airborne yeast of the Senne River Valley to spontaneously ferment their product even though fermentation methods have advanced dramatically. Indeed, Figure 5, shown earlier, reveals that the vast majority of spontaneous fermentation beer breweries are located where they have always been-along or near the Senne River. Likewise, laws no longer require beer in the village of Halle to employ a mash with 300 liters of wheat and 500 liters of barley and oats, but brewers continue to follow this 1559 regulation 
since a change in recipe could be costly in terms of upsetting loyal customers. We attribute this to “behavioral lock-in" as outlined by Stack et al. (2016) and Dighe (2017). Similar examples of such behavioral lock-in can be found in the production of Old Brown and Red Brown beer in the cities of Oudenaarde and Roeselare, which both institutionalized specific production methods. Brewers in these cities continue to follow the old methods and largely employ the same ingredients even though these rules are no longer binding.

Another example of path dependence in Belgium brewing can be found in the topfermented Saison (Season) variety, which originated in the French part of Belgium. The oldest Saison recipe dates to 1785 from a brewery in Hainaut. Farm workers in Hainaut had little to do in the winter months so they used this time to produce a beer that could be stored and consumed in the summer. As modern refrigeration methods were not yet invented, the brew was strongly seasoned in ways consistent with the gruit of past brewing and it was also heavily hopped. The combination of these two preservation methods dramatically enhanced the beer's longevity. The use of both hops and gruit-like herbs in these beers is particularly interesting in light of the fact that the Hainaut region changed hands (and institutional regimes) several times between the "French" who were slower to adopt hops (and hence employed gruit longer) and the "Germans" who were early adopters of hops in beer. Of course refrigeration and beer stabilization methods have improved dramatically over the last two centuries, but Saison beers, which have seen a major resurgence in the last two decades, are still both heavily hopped and seasoned. Figure 3, which was shown in the section 3, shows that today's Saison beer producers continue to be disproportionately located in the French part of the country, and mostly in or near the Hainaut province where farmers first made the variety nearly 250 years ago. 
The Trappist breweries are also still producing their beers on the locations (see Figure 4) that are a function of past institutional upheaval. All six Belgian Trappist breweries, which were founded after the Belgian Constitution re-introduced the freedom of religion, are located close to the national border. Van den Steen (2011) argues that the abbeys choose such locations so that it would be easy to flee in the event of another regime change whereby they were no longer welcome.

\section{Path Dependence in the Postwar Era: Many Historic Brews Remain}

Between World War II and 1980, the percentage of imported beer in Belgium rose from under 1 percent to 7.5 percent. German lagers and English ales made up the vast majority of these imports. Many Belgian brewers responded to this rising competition, however, not by becoming more like the Germans and English, but instead by doubling down on the production of their historic beer varieties. In fact, Belgian consumers had remained largely loyal to their local brews while lager beer, which was introduced to Belgium in the interwar years, remained less popular. Lager consumption did rise in the 1960 s as it was seen as the 'brew of progress.' However, during the 1970s there was an increase in so-called "nostalgic consumption" whereby Belgium saw a sharp rise in the production of its longstanding native varieties-Old Brown, Lambic, Saison, Witbier, Red Brown, and Gruitbeer, among others. ${ }^{38}$

Since the 1980s, Belgium, like most other major beer producing countries, has seen a surge in the entry of small breweries. A large literature exists which discusses the global emergence of these small-scale breweries (see Carroll and Swaminathan, 1992, 2000; Swaminathan, 1998; Cabras and Bamforth, 2016; Garavaglia and Swinnen, 2018). Interestingly, however, Belgium does not have a term for the phenomenon coined "craft beer" in the United States and "real ale" in

\footnotetext{
${ }^{38}$ Kredietbank.(1968: 284, 382); (1975: 2-3) and (1987: 1-3) and Jansen (1987: 215-217).
} 
the United Kingdom (Poelmans and Swinnen, 2018). We believe that this is because Belgian consumers have long been accustomed to a wide diversity of locally produced beer that employs a variety of ingredients - something that certainly was not true in most other countries where the craft-brewing movement has taken off both in numbers and in nomenclature. As Swinnen and Briski state (2017) Belgium "has to some extent always been a craft beer nation."39

In an application of Garud and Karnoe’s (2001) “path creation,” whereby economic actors play an important role in shaping their environment, and Heikkila's (2011) insight that a player's knowledge of the earlier path shapes current decisions, the trend of Belgian brewers emphasizing their historic production has been widely promoted by the Belgian national government and the local governments of several Belgian cities. Many localities have attempted to attract beer tourism through the establishment of beer museums that highlight the long history of brewing in their regions. Furthermore, many cities today produce their own "city beer" by following an historic recipe unique to the area. Notable examples include Aarschotse bruine in Aarschot, Seefbier in Antwerp, and the five different gruitbeers in Gent, which duplicate the gruit used centuries ago. ${ }^{40}$ This has further added to Belgium's reputation as a mecca of beer diversity.

\section{Explaining Beer Varieties that are Produced all across Belgium}

That is not to say that all Belgian brewing is tied to historic varieties. Belgium's bestselling exported beer, Stella Artois, is a Pilsner which was created in 1926. Today, Lager beer, which includes Pilsner as a sub category, makes up around two-thirds of all Belgian beer production. ${ }^{41}$

\footnotetext{
39 This reemergence of old native beer varieties in Belgium since the 1970s (as opposed to lager beer) after a small decrease in the 1960s, is visible in the data: while the market share of lager beer had risen from 55 percent in 1947 to 80 percent in 1975, this share had subsequently fallen to 70 percent by 2000 and to below 50 percent today (Poelmans and Swinnen, 2018: 145 and 147).

${ }^{40}$ Degrande (2009: 142) and Anonymous (9 March 2012).

${ }^{41}$ Persyn et al. (2011: 81).
} 
Figure 6 shows that unlike most other major beer varieties, Pilsner is produced in every one of Belgium's 10 provinces. This geographic production pattern is consistent with our institutional story. Pilsner is not native to the Belgium area as it was not produced in Belgium until the end of the $19^{\text {th }}$ century and then only in very small quantities - it was not until the interwar era that production of Pilsner took off in Belgium. When Pilsner production began in the area, Belgium land mass was all under the same institutional regime. Hence there is no compelling institutional reason why its production should be region specific. ${ }^{42}$ It is also noteworthy that the Belgian Abbey Beer producers, which tend to produce higher-alcohol brews are also widely dispersed throughout Belgium, appearing in 9 of the 10 provinces (Figure 7). Again, this geographic distribution is consistent with our story. The institution that brought about the proliferation of high-alcohol beer in the post-WWI era-i.e. the prohibition of sales of spirits in restaurants and pubs—affected the whole of Belgium rather than having a heterogeneous effect on sub-regions within the nation. ${ }^{43}$

A third beer variety that can be found all over Belgium today is the Witbier (Figure 8). Although Witbier is a variety that is native to $16^{\text {th }}$ century Brabant, by the mid- $20^{\text {th }}$ century its production had died out. In 1966, Pierre Celis started producing Hoegaarden beer in a village by the same name in Flemish Brabant, near where the first Witbiers were historically produced. This started a major Witbier revival. In fact, many Belgian breweries today produce at least one Witbier. We posit that the reason this beer is produced nationally — whereas other historic varieties such as

\footnotetext{
${ }^{42}$ There are several potential explanations for the slow spread of Lager/Pilsner beer in Belgium. First, there were high fixed costs (new equipment) that had to be made in order to brew lager beer. Furthermore, as previously mentioned, a tax from 1821 that focused on the size of the fermentation tubs favored the traditional top fermentation method. This law significantly penalized lager brewing because of the longer maturation time and hence requirement for larger fermentation tubs. This law was not amended until 1885 and after this time several new bottom-fermentation breweries appeared in Belgium. Van Velsen (1900: 78); Kredietbank. (1938: 94) and Segers and Dejongh (2000: 18).

${ }^{43}$ Although some of today's officially recognized Belgian abbey beers are brewed within the abbey walls, others are merely partnered with an old or existing monastery, but are brewed by an industrial (very often large) brewer. For instance Leffe, referring to the Premonstratensian/Norbertins of Leffe, in the province Namur is today brewed by AB InBev.
} 
Old Brown and Saison are generally produced in their places of origin - is that the breweries that had previously made Witbier had completely vanished or moved on to other varieties. In contrast, many of today's producers of other historic varieties such as Old Brown and Saison have been producing this variety of beer for centuries. ${ }^{44}$

\section{Conclusion}

Institutions matter. The legal regimes that operate in the background play a large role in the economic development of a geographic area. This paper shows that institutions played an important role in shaping the direction of Belgium's beer industry over time. Despite its relatively small size, Belgium has historically been considered to have the most diverse array of beer varieties in the world. Many of the varieties for which Belgium is well known, such as Old Brown, Red Brown, Gruitbeer, Saison, Lambic, and Trappist, continue to be produced today in the geographically-specific regions within the nation in which they began. We argue that many of these beer types were developed in response to specific institutional changes that heterogeneously affected the areas in which they were created. That these historic varieties continue to be produced in these areas can be viewed through the lens of path dependence-the old methods have become entrenched either through technological or behavioral lock-in, as outlined by Stack, Gartland, and Keane (2016) and Dighe (2017).

To illustrate, institutions directly influenced the speed and extent to which hops were employed in beer production in different parts of Belgium. The 1364 decree Novus Modus Fermentandi Cerevisiam of Holy Roman Emperor Charles IV permitted local rulers to tax hops

\footnotetext{
${ }^{44}$ As mentioned in the theoretical section, the theory of path dependency suggests that multiple paths are initially possible. Poelmans and Taylor (2019) discuss various counterfactuals to the Belgian experience such as that of Germany and the United States whereby different institutional conditions held.
} 
rather than relying, as they had previously, only on the sale of gruit (a mixture of herbs traditionally employed to preserve and flavor beer) for revenue. Around three-quarters of present-day Belgium-generally land east of the Scheldt River-was affected by the Novus. Brewers in Brabant, who were impacted by the Novus, quickly adopted hops and the region became a large hub of brewing production. In the western part of Belgium, where the Novus had no effect, the use of hops remained less popular for centuries, even long after hops were formally allowed there. For example, Old Brown beer, whose production can be traced to 1545 in the village of Oudenaarde, is highly acidified rather than being hop-centric. Old Brown beer continues today to be produced west of the Scheldt River. Furthermore, today many Gruitbeers are produced west of the Scheldt River in homage to the recipes of the past.

Legal restrictions on the ingredients and brewing methods of beer also played a role in creating Belgium's diverse beer production. In Bavaria the Reinheitsgebot has for five centuries restricted brewers to the use of three ingredients - water, hops, and barley (and later yeast). Such strict limitations on ingredients stifle the diversity of beer varieties within their affected regions. While Belgian villages were sometimes subject to Reinheitsgebot-like legal restrictions on brewing - which were generally imposed to limit tax evasion-these restrictions varied widely from village to village. For example, a 1559 law in the village of Halle required brewers to use a mash with precise quantities of wheat, barley, and oats while a 1615 decree in the village of Hoegaarden required brewers to use malt, wheat, and oats in proportions that were different than in Halle. In Namur, a 1606 charter explicitly outlined the ingredients that could be used in bière de Namur. Similarly, the villages of Oudenaarde and Roeselare specified precisely how long the malt had to be dried and how long the wort had to be cooked when brewing Old Brown and Red 
Brown beer. Today, brewing in many of these villages continues to follow these traditions even though these regulations are no longer applicable.

While beer varieties whose formation can be tied to institutional changes prior to Belgium independence generally continue to be primarily produced in the sub-regions where they began, there have been important institutional changes since 1830 which have homogeneously affected the entire nation. For example Belgium's Vandervelde prohibition law forbade spirits to be sold in restaurants or pubs, but allowed beer. To fill this gap, brewers produced beer with higher alcohol content and today Belgium is well known for its Dubbels and Tripels, which are generally between 7 and 12 percent alcohol by volume. Because this institutional change affected the whole of Belgium, these beer types, many (but not all) of which fall under the category of Abbey Beer, are today produced all over the country.

Institutional change is certainly not the only factor that has influenced the development of Belgian beer. Still, this paper argues that it is no coincidence that the relatively small Belgian nation has such strong diversity in both its institutional history and its historic beer varieties - we show that the former contributed heavily to the latter. This paper adds to the broader literature arguing that institutions are an important factor in a region's economic development (Olson, 1996; Hall and Jones, 1999; Rodrik et al. 2004; Grief, 2006). Furthermore, the fact that local governments within Belgium today promote their area's historic brewing tradition via museums and campaigns to advance its historic beer varieties offers a real-world application of Garud and Karnoe (2001) and Heikkila (2011), who argue that economic actors often play an important role in shaping and maintaining path dependencies. Thus, the historical development of Belgian beer provides economists with another valuable real world example of how institutions shape the world. 


\section{References}

Alworth, J. (2015), The Beer Bible, New York: Workman Publishing.

Anonymous. (10 July 1908), 'La brasserie Namuroise Aux Siècles Passés', Le Petit Journal du Brasseur, 16(726): 551-563.

Anonymous. (7 May 1909), 'La 'Bière Blanche' de Hougaerde', Le Petit Journal du Brasseur, 17(766): 489-494.

Anonymous. (9 March 2012), 'Verloren Gewaand Bier Gelanceerd in Antwerpen' De Volkskrant, 9th March 2012. See: http://www.volkskrant.nl/magazine/verloren-gewaand-biergelanceerd-in-antwerpen $\sim 3223028$

Arthur, W.B. (1988), 'Self-reinforcing Mechanisms in Economics', in P. W. Anderson, K. J. Arrow and D. Pines (eds.), The Economy as an Evolving Complex System, Redwood City: Addison Wesley.

Arthur, W.B. (1989), 'Competing Technologies, Increasing Returns, and Lock-In by Historical Events', Economic Journal, 99: 116-131.

Beckmann, J. (1814), A History of Inventions and Discoveries, Volume IV, London: George Bell and Sons.

Belgische brouwers (BB). (December 1993), Het Brouwersblad, 100.

Belgische brouwers (BB). (April 1997), Het Brouwersblad, 104.

Belgische Brouwers (BB). (2014), Jaarverslag 2014.

Belgische Dienst voor de Buitenlandse Handel. (1986), Belgisch Bier: Schuimende Traditie, Beproefde Proceskennis - La Bière Belge: Une Tradition Savoureuse, un Savoir-faire éprouvé, 85(3), Brussel: B.D.B.H..

Cabras, I, and C. Bamforth (2016), 'From Reviving Tradition to Fostering Innovation and Changing Marketing: The Evolution of Micro-brewing in the UK and US, 1980-2012', Business History, 58(5-6): 625-646.

Cappelle, C. (2010), Bruin. De geschiedenis van het brouwen in en rond Oudenaarde sinds 1357, Oudenaarde: Uitgeverij Beatrijs.

Carroll, G. and A. Swaminathan (1992), 'The Organizational Ecology of Strategic Groups in the American Brewing Industry from 1975 to 1990', Industrial and Corporate Change, 1(1): 65-97. 
Carroll, G. and A. Swaminathan (2000), 'Why the Microbrewery Movement? Organizational Dynamics in the US Brewing Industry', American Journal of Sociology, 106(3): 715762.

Cowan, R. (1990), 'Nuclear Power Reactors: A Study in Technological Lock-in', Journal of Economic History, 50: 541-567.

Deconinck, K., E. Poelmans, and J. Swinnen (2016a), 'How Beer Created Belgium (And the Netherlands): The Contribution of Beer Taxes to War Finance During the Dutch Revolt', Business History, 58(5-6): 694-724.

Deconinck, K. and J. Swinnen (2016b), 'Tied Houses: Why They are So Common and Why Breweries Charge Them High Prices for Their Beer', in I. Cabras, D. Higgins, and D. Preece, Brewing, Beer and Pubs: A Global Perspective, Basingstoke: Palgrave Macmillan (231-246), pp. 231-246.

Degrande, G. (2009), Tournée Générale: De Geheimen Van Het Belgische Bier, Leuven: Uitgeverij Van Halewyck.

Dejongh, G. (1995), 'Een Nationale Drank, een Nationale Industrie: De Ontwikkeling Van de Biernijverheid', in B. Van Der Herten, M. Oris, and J. Roegiers (eds.), Nijver België: het industriële landschap omstreeks 1850, Brussel: Gemeentekrediet.

Deutscherbrauer-bund e.V. (2015), Das Reinheitsgebot Sichert Seit Fast 500 Jahren Wie BierQualität, Berlin. Retrieved from: http://www.brauer-bund.de/bier-istrein/reinheitsgebot.html

Deweer, H. (2015), All Belgian Beers - Alle Belgische Bieren - Toutes les Bières Belges, Oostkamp: Stichting Kunstboek.

Dighe, R. (2016), 'A Taste for Temperance: How American Beer Got to be so Bland', Business History, 58(5-6): 752-784.

Dighe, R. (2017), 'The Craft Beer Explosion: Why Here? Why Now?', Process: A Blog for American History, (http://www.processhistory.org/craft-beer-dighe/)

Engel, C. and E.U. Weber (2007), 'The Impact of Institutions on the Decision How to Decide', Journal of Institutional Economics, 3(3): 323-349.

Garavaglia, C. and J.F.M. Swinnen (2018), Economic Perspectives on Craft Beer. A Revolution in the Global Beer Industry, Cham, Switzerland: Palgrave MacMillan.

Garud, R. and P. Karnoe (2001), 'Path Dependence and Creation', in R. Garud and P. Karnoe (eds.), Path Dependence and Creation, London: Lawrence Erlbaum Associates, pp. 138. 
laeser, E.L., R. La Porta, F. Lopez-De-Silanes, and A. Shleifer (2004), 'Do Institutions Cause Growth?', Journal of Economic Growth, 9(3): 271-303.

Greif, A. (2006), Institutions and the Path to the Modern Economy: Lessons from Medieval Trade, New York: Cambridge University Press.

Hall, R.E. and C.I. Jones (1999), 'Why Do Some Countries Produce So Much More Output Per Worker Than Others?', The Quarterly Journal of Economics, 114(1): 83-116.

Hansen, B. and M.E. Hansen (2007), 'The Role of Path Dependence in the Development of US Bankruptcy Law, 1880-1938', Journal of Institutional Economics, 3(2): 203-225.

Heikkila, E.J. (2011), 'An Information Perspective on Path Dependence', Journal of Institutional Economics, 7(1): 23-45.

Hornsey, I. (2003), A History of Beer and Brewing, Cambridge: The Royal Society of Chemistry.

Jackson, M. (1991), The Great Beers of Belgium: A Complete Guide and Celebration of a Unique Culture, Antwerpen: Albe.

Jansen, A.C.M. (1987), Bier in Nederland en België: Een Geografie van de Smaak, Amsterdam: Universiteit van Amsterdam.

Kredietbank (25 March 1938), 'De Evolutie der Belgische Bierbrouwerij (1/2)', Weekberichten van de Kredietbank, 3( 6): 90-98.

Kredietbank (19 October 1968), 'De Belgische Biernijverheid', Weekberichten van de Kredietbank, 23(39): 381-385.

Kredietbank (5 September 1975), 'Bier Nog Steeds de Nationale Drank', Weekberichten van de Kredietbank, 3(33): 1-5.

Kredietbank (11 December 1987), 'België, Bierparadijs', Weekberichten van de Kredietbank, 42(45): 1-6.

Lacambre, G. (1851), Traité Complet de la Fabrication des Bières et de la Distillation des Grains, Brussels: Librairie Polytechnique d'Aug.

Levi, M. (1997), 'A Model, a Method, and a Map: Rational Choice in Comparative and Historical Analysis,' in M. Lichach and A. Zuckerman (eds.), Comparative Politics: Rationality, Culture and Structure, Cambridge: Cambridge University Press.

Liebowitz, S.J., and S.E. Margolis (1990), 'The Fable of the Keys', Journal of Law and Economics, 33:1-25. 
Liebowitz, S.J. and S.E. Margolis (1995), 'Path Dependence, Lock-In, and History', Journal of Law, Economics, and Organization, 11: 205-226.

Meloni, G. and J. Swinnen (2013), 'The Political Economy of European Wine Regulations', Journal of Wine Economics, 8(3): 244-284.

Meloni, G., and J. Swinnen (2016a), 'The Political and Economic History of Vineyard Planting Rights in Europe: From Montesquieu to the European Union', Journal of Wine Economics, 11(3): 379-413.

Meloni, G. and J. Swinnen (2016b), 'Chocolate Regulations', in M.P. Squicciarini and J. Swinnen (eds.), The Economics of Chocolate, Oxford: Oxford University Press, pp. 268-306.

Meloni, G. and J. Swinnen (2018), 'Trade and Terroir; The Political Economy of the World's First Geographical Indications.' LICOS Discussion Paper 400/2018.

North, D (1990), Institutions, Institutional Change and Economic Performance, Cambridge, MA: Cambridge University Press.

North, D.C. (1993), 'The New Institutional Economics and Development,' Washington University Working Paper, St. Louis. http://www2.econ.iastate.edu/tesfatsi/NewInstE.North.pdf.

Olson, M. (1982), The Rise and Decline of Nations: Economic Growth, Stagflation, and Social Rigidities, New Haven: Yale University Press.

Olson, M. (1996), 'Distinguished Lecture on Economics in Government: Big Bills Left on the Sidewalk: Why Some Nations are Rich, and Others Poor', Journal of Economic Perspectives, 10(2): 3-24.

Patroons, W. (1979), Bier, Antwerpen: Standaard Uitgeverij.

Persyn, D., J. Swinnen, and S. Vanormelingen (2011), 'Belgian Beers: Where History Meets Globalization', in J. Swinnen (Ed.)., The Economics of Beer, Oxford: Oxford University Press, pp. 79-106.

Perrier-Robert, A. and C. Fontaine (1996), België Door Het Bier. Het Bier Door België, Esch-surAlzette: Uitgeverij Schortgen.

Peumans, H. (1938), 'Courte Esquisse de L'évolution de L'industrie Brassicole Belge Depuis 1830', Bulletin Trimestriel de L'association des Anciens élèves de L'école Supérieure de Brasserie, 38(1): 71.

Poelmans, E. and J.F.M. Swinnen (2011a), 'From Monasteries to Multinationals and Back: An Economic History of Beer', The Journal of Wine Economics, 6(2): 196-216. 
Poelmans, E. and J.F.M. Swinnen (2011b), 'A Brief Economic History of Beer', in: J.F.M. Swinnen (ed.), The Economics of Beer, Oxford: Oxford University Press, pp. 3-28.

Poelmans, E. and J. Swinnen, (2018), 'Belgium: Craft Beer Nation?', in C. Garavaglia and J.F.M. Swinnen, Economic Perspectives on Craft Beer. A Revolution in the Global Beer Industry, Cham, Switzerland: Palgrave MacMillan, pp. 137-160.

Poelmans, E. and J.E. Taylor (2019), 'Different Paths, Different Outcomes: The Role of Institutions and Path Dependency in Various Beer-Producing Nations', Working Paper, Department of Economics, Central Michigan University.

Puffert, D.J. (2002), 'Path Dependence in Spatial Networks: The Standardization of Railway Track Gauge', Explorations in Economic History, 39: 282-314.

Rodrik, D., A. Subramanian and F. Trebbi (2004), 'Institutions Rule: The Primacy of Institutions Over Geography and Integration in Economic Development', Journal of Economic Growth, 9: 131-165.

Scholliers, P. (1996), 'Een Vijand die Men Kennen Moet' Jenever in België in de 19de en Vroeg 20ste Eeuw', in E. Van Schoonenberghe (ed.), Jenever in de Lage Landen, Brugge, Belgium: Stichting Kunstboek, pp. 139-157.

Segers, Y and G. Dejongh (2000), 'De hoofdelijke voedselconsumptie in België, 1830-1913. Reconstructie dataset en analyse', in E. Buyst., G. Dejongh, R. Loyen and Y. Segers (eds.), Op weg naar een consumptiemaatschappij. Over het verbruik van voeding, kleding en luxegoederen in België en Nederland (19de-20ste eeuw), Amsterdam: Uitgeverij Aksant, pp. 1-31.

Smith, A. and B. Yandle (2014), Bootleggers and Baptists: How Economic Forces and Moral Persuasion Interact to Shape Regulatory Politics, Washington DC: The Cato Institute.

Stack, M. (2000), 'Local and Regional Breweries in America’s Brewing Industry, 1865 to 1920', Business History Review, 74: 435-463.

Stack, M. and M. Gartland (2003), 'Path Creation Path Dependency, and Alternative Theories of the Firm', Journal of Economic Issues, 37: 487-94.

Stack, M. and M. Gartland (2005), 'The Repeal of Prohibition and the Resurgence of the National Breweries: Productive Efficiency or Path Creation?', Journal of Management History, 43(3): 420-432.

Stack, M., M. Gartland, and T. Keane (2016), 'Path Dependency, Behavioral Lock-in and the International Market for Beer', in I. Cabras, D. Higgins, and D. Preece, Brewing, Beer and Pubs, London: Palgrave Macmillan, pp. 54-73.

Swinnen, J. and D. Briski (2017), Beeronomics. How Beer Explains the World, Oxford, UK: Oxford University Press. 
Swinnen, J. (2017), 'Some Dynamic Aspects of Food Standards', American Journal of Agricultural Economics, 99(2): 321-338.

Tollet, A. (2015), Vlaams-Brabant Drinkt: Bier-en Jenevercultuur Sinds 1800, Leuven: Openbaar Kunstbezit Vlaanderen.

Unger, R.W. (2001), A History of Brewing in Holland, 900-1900, Economy, Technology, and the State, Leiden and Boston: Brill Academic Publishers.

Unger, R.W. (2004), Beer in the Middle Ages and the Renaissance, Philadelphia: University of Pennsylvania Press.

United States Brewers Association (1979), Brewers Almanac, Washington, DC: United States Brewers Association.

Van den Steen, J. (2011), Trappist: De Zeven Heerlijke Bieren, Leuven: Uitgeverij Davidsfonds.

Vanrafelghem, S. (2013), Tournée Générale 3: Trends en Tradities, Leuven: Uitgeverij Van Halewyck.

Van Uytven, R. (2007), Geschiedenis van de Dorst. Twintig Eeuwen Drinken in de Lage Landen, Leuven: Uitgeverij Davidsfonds.

Van Velsen, V. (1900), 'Réforme et Simplification du Régime Fiscal Belge', in Congrès de Brasserie en 1900 à Paris. Travaux Préparatoires. B. Mémoires Belges, Brussels : Ad. Mertens.

Verdonck, E. and L. De Raedemaeker (2016), The Belgian Beer Book, Tielt: Lannoo Publishers.

Voigt, S. (2013), 'How (Not) to Measure Institutions', Journal of Institutional Economics, 9: 126.

Webb, T. and S. Beaumont (2012), The World Altlas of Beers, London: Mitchell Beazley.

Yandle, B. (1983), 'Bootleggers and Baptists: The Education of a Regulatory Economist', Regulation, 7(3): 12-16. 